\title{
Students' Attitude Towards Entrepreneurship Education in Edo State: A Case of Three Tertiary Institutions
}

\author{
ADEOYE, Jacob Oruamen, ISERE, Victoria Oshuare Merab, IMONIKHE, Justina Selimetu \\ Department of Humanities \& Social Sciences, School of General Studies, Auchi Polytechnic, Auchi
}

\begin{abstract}
Every country faces the challenges posed by unemployment and shrinking economies and while some are winning, more are actually in and out of recession as the years roll by.. This trend has opened up the need to help more people become entrepreneurial. Entrepreneurship will help improve job availability. The population of the study consisted of all final year students from three tertiary institutions in Edo state. The population of the final year students in these three tertiary institutions was about 30,000 during the 2019/2020 academic section from which a sample of 529 respondents were randomly selected using the simple random sampling technique. The study revealed among others that there is significant difference between gender as well as area of study and student's attitude towards entrepreneurship education; and also that there is no significant difference between age and students' attitude towards entrepreneurship education. The study recommends that students should be assisted to have free hands-on-training in industries of their choice during holidays so they can practicalize the theories learnt in class and that the lectures and practical sections should be made more attractive by giving specialized training to entrepreneurship educators and resource persons.
\end{abstract}

Keywords: entrepreneurship, entrepreneurship education, unemployment, attitude, Edo state

DOI: $10.7176 / \mathrm{JPID} / 59-05$

Publication date: February $28^{\text {th }} 2021$

\section{Introduction}

The globalization of the world has had its impact on individual nations too; arising from uncertainty and complexity of globalization. Markets are trying to break down the complexity but the job offerings are limited irrespective of the level of education (Allawadi, 2010) in most countries. Many nations are unprepared for globalization. They are still in limbo as to where exactly they stand economically.

Every country faces the challenges posed by unemployment and shrinking economies and while some are winning, more are actually in and out of recession as the years roll by. Unemployment is one burden of governments all over the world as it is generally known to lead to increase in other vices such as social unrest and youth restiveness. The need to employ more is loud and clear and every responsible government is deeply concerned and actively seeking for solution. While some nations have expanded production and employment capacity others have only increased consumption for imports; shrinking their capacity for employment generation. This trend has opened up the need to help more people become entrepreneurial. Entrepreneurship, no doubt will help improve job availability while ensuring economic growth and poverty reduction. Entrepreneurship is the creation or extraction of value. It is the process of designing, launching and running a new business which is often initially a small business. (Wikipedia, 2020).

Entrepreneurship education will help contribute to the development of manpower needed for employment generation, poverty reduction and economic growth. On a yearly basis, thousands of graduates are added to the labour market and if these graduates are not trained entrepreneurially, they will worsen the level of unemployment especially in developing countries like Nigeria. Entrepreneurial training is designed for self employment and thereby development of the nation. It incorporates skill training into the usual learning experience given to these students before they graduate - giving them the privilege to be self-employed and even employers of labour.

Nigeria is blessed with vast vegetation and population. However much of her population live on less than $\$ 1$ a day and over 70\% are unemployed as reported by World Bank (2018) in Ango \& Kyari (2018) while her inflation rates have remained high (over 14\%) for many years now. They reported that the Asian Tigers were able to achieve their feat of economic upturn due to orientation and capacity training for spontaneous response from entrepreneurship education and skill training.

The bedrock of the development of any nation is in education. The Nigerian National Policy on Education is intended to integrate the individual into a sound and effective citizen and thus should not just give certificates but work-oriented ones (Adebayo \& Kolawole, 2013). One of the seven goals of National Policy on Education for tertiary education is to acquire both physical and intellectual skills which will enable individuals to be self-reliant and useful members of the society. (FRN, 2004).

Entrepreneurship education in tertiary institutions is meant to provide students with skill and motivation to engage in entrepreneurial activity in addition to their main course of study as having a degree is no long a guarantee for employment as opined by Ajike, Nnorom, Akinlabi, Onyia \& Kwarbai, 2004). Entrepreneurship education is not just about passing instructions but an actual preparation and training of the students for productive and 
successful participation in the real world. The importance of this is being constantly revealed today. Entrepreneurship education seeks to provide students with the knowledge, skills and motivation to encourage entrepreneurial success in a variety of settings. Entrepreneurship is the willingness to take risks and develop, organize and manage a business venture in a competitive global market place that is constantly evolving. Entrepreneurs are pioneers, innovators, leaders and inventors. Markets have more space for entrepreneurs than for job seekers.

Entrepreneurship education refers to education that helps shape attitude favourably towards entrepreneurship. It should include how to identify and seize business opportunities; making decisions about markets and marketing strategies. It is imperative for positive contribution towards improving the entrepreneurial prowess of students after graduation. Entrepreneurship education was introduced to undergraduates in both universities and polytechnics by the Federal government through the National Universities Commission.

In a time of lack of white-collar jobs as it is with Nigeria and most developing countries today, the need for Entrepreneurship Development is overwhelming. The Nigerian government decided to bring this course into tertiary education not as a discipline but as part of the training received by every undergraduate (irrespective of their main discipline) in Nigeria. Despite the number of years that the tertiary system has been training would-be entrepreneurs we see a lacuna in the real world. Students are trained to be self employed yet the cry for whitecollar jobs is increasing annually and this situation is worrisome. It is against this background that the researchers seek to investigate students attitude towards entrepreneurship in tertiary institutions in Edo state, Nigeria.

\section{Theoretical framework}

The theoretical framework for this study is hinged on the social constructivism theory of learning. Learning is the individual growth of a person as a result of cooperative interaction with others. Learning has taken place if the student behaves, reacts and responds as a result of experiences differently from former behavior. Learning theories describes how students receive, process and retain knowledge during learning. Wikipidia (2020) acknowledges that cognition, emotion, environmental influences and prior experience all play a part in how knowledge is acquired and skills gained.

According to the Graduate Student Instructor (GSI) Teaching and Resource Center (2020), there are many different approaches to learning. However the three basic types of learning theory are:

* Behaviorism

* Cognitive constructivism

* $\quad$ Social constructivism

Behaviorism views knowledge as a repertoire of behavioural responses to environmental stimuli while the cognitive constructivism perceives knowledge as a system built up by the learner actively from pre-existing cognitive structure. Social constructivism presents knowledge as constructed within social contexts through interactions in a knowledge community.

The Behaviorist theory view learning as passive absorption promoted by repetition and positive reinforcement. The cognitive constructivists view learning as active absorption where discovery is emphasized; while the social constructivists view learning as integration of students into a community of knowledge. Absorption is collaborative.

Shortly put, the behaviorist looked at learning as conditioning and they advocate a system of rewards and targets Constructivist believe a lot in knowledge being acquired largely from what the students already know as an individual (cognitive constructivism) or in a knowledge community (social constructivism).

\section{Concept of entrepreneurship and entrepreneurship education}

Education means to train the mind, character and abilities of an individual. It is a fundamental human right. (Isere \& Imonikhe, 2018) and according to Lawal (2016) it is the light that drives away the darkness of ignorance; salt that gives taste to life; drug that cures all diseases and keys to unlock the doors of personal and national development. Education is a very important tool for today's knowledge-based economies. It is a corner-stone of economic growth and social development and Alika (2013) describes it as a principal tool for enhancing the welfare of citizens. According to Wikipedia (2020), education is the process of facilitating learning and includes teaching, training, discussion and directed research with a formative effect on the way one thinks, feels and acts.

Entrepreneurship refers to the concept of developing and managing a business venture in order to make gain/profit. It is the desire and willingness to start a new business. According to Hisrich (2002) cited in Adebayo \& Kolawole (2013) entrepreneurship is the process of creating something new with values by devoting the necessary time and effort; assuming accompanying financial, psychic and social risks to reap the resulting rewards of monetary and personal satisfaction and independence. Entrepreneurship is a way to bridge the gap between discovery and the market place and it is the most effective way despite the troubles encountered before getting to the market place.

A well functioning market economy is made possible by a multitude and diversity of enterprise. These 
enterprises are run by entrepreneurs and are the most important engines of economic, technological and social changes in society today. An entrepreneur is anyone who is willing to work for and by himself. The entrepreneur is an enterprising individual who takes on risks and initiative knowing there are gains therein (Ojiefo, 2012). Entrepreneurs are made through education/training. Thus a course in entrepreneurship is a specialized training to acquire skills, ideas and managerial abilities and capacity for self-employment and wealth creation. Entrepreneurship education exposes the student to some of the basic skills which encourages them to become entrepreneurial. Entrepreneurship education in Nigeria seeks to provide knowledge, skills and motivation to encourage entrepreneurial intention in students in tertiary institutions. Hence it is offered by undergraduates as a compulsory general studies course across the country with the aim to inculcate the spirit of self reliance in them.

Entrepreneurship education will address the problem of unemployment overtime and also ensure a pool of entrepreneurial human capacity for National Development. (Ojeifo, 2012). According to Paul, (2005) in Ojeifo (2012), entrepreneurship education has some objectives which include to provide graduates with adequate training that will enable them to be creative and innovative in identifying novel business opportunities to reduce poverty and serve as a catalyst for economic growth and development. The European Commission (2011) defines entrepreneurship education as a process by which learners are equipped with a wide range of competencies that can bring about greater individual, social and economic benefits. So entrepreneurship education is that type of education designed to prepare learners for innovative ventures leading to self reliance and financial emancipation.

There are different levels of entrepreneurship education offered at all levels of education - from primary to tertiary - all in a bid to awaken skill and initiative in the learners. (Okoli \& Allahna, 2014). Most children in Nigeria today are into various skill training in an after-school arrangement. All this is to fight the growing menace of unemployment.

A lot of research has been done on the attitude of students across various countries of the world. Rudhumbu, Svotwa, Munyanyiwa \& Mutsau (2016) studied the attitudes of 250 final year students towards entrepreneurship education in two selected tertiary institutions in Botswana. A 5-point likert scale was employed for data collection. The results showed positive attitude towards entrepreneurship education. They also showed a positive attitude towards being entrepreneurs after schooling. There was a significant relationship between gender and attitude to entrepreneurship education; there was no significant relationship between main course of study and attitude to entrepreneurship education while there is significant relationship between age and attitude to entrepreneurship education.

Hussain, Hashmi \& Gilani (2018) reported concerning India in their explorative study on attitude of 135 technology education students towards entrepreneurship education that there was no significant difference in terms of gender among full time student but there was among self-supporting students. They reported a positive attitude generally towards entrepreneurship education.. Buba, Ayuba \& Rimamnde (2015) studied the effects of entrepreneurship education on university students' attitude to entrepreneurship intentions using five universities in North east Nigeria. They reported a positive relationship between offering entrepreneurship education and the intention to become entrepreneurs. Otu, Eduwem, \& Umoinyang (2017) also reported a positive and significant attitude towards entrepreneurship education by students of the University of Calabar. They investigated this using a sample of 225 students.

Abdelraheem \& Rand (2019) reported significance difference in attitude of 311 students at the Princess Sumaya University of Technology in India based on demographic characteristics like age, gender and whether their mothers had their own business. Amanamah (2017) investigated the attitude of 788 Ghanaian students from a tertiary institution towards entrepreneurship education and reported a positive attitude towards it. With regards to marital status, there was a significant difference as unmarried students were more likely to go into entrepreneurship than the married one.

Pulka, Rikwentishe \& Ibrahim (2014) with the aim to examine the cognitive, affective, and behavioural components of students' attitude and to examine the overall attitude of students towards Entrepreneurship education in five selected universities in North East Nigerian reported a strong positive attitude towards entrepreneurship education of the students generally and a strong desire to engage in entrepreneurial activities. They study also reported positive behavioural tendency, favourable cognitive and strong affective towards entrepreneurship education. Ango \& Kyari (2018) in their study on undergraduate students' attitude towards entrepreneurship education in Kaduna State University using a sample size of 400 final year students revealed no significant difference in attitude between male and female students. They however reported a significant difference in attitude of students' from different faculties towards entrepreneurship education. Adeeko, Bifarin \& Umunna (2016) reported that students in Ondo state had a good perception towards entrepreneurship and entrepreneurship education. Their study revealed that students began their entrepreneurial businesses with little savings and the teaching from classes encouraged about $95 \%$ of the respondents to desire to go into business. Lawan, Envuladu, Mohammad, Wali \& Mahmoud (2015) reported negative attitude (up to 84\% of the respondents) towards entrepreneurship among final year undergraduate students in Kano. They also reported that the students feel the course is inadequate in scope and should be more specific to each student's area of study. 


\section{Research questions}

This study is guided by the following research questions:

a. What is the general attitude of students towards entrepreneurship education?

b. Does age, gender or course of study affect students attitude towards entrepreneurship education?

c. Is the current organization of entrepreneurship education satisfactory to the students?

\section{Hypotheses}

$\mathrm{H}_{01}$ : There is no significant difference between gender and attitude of students towards entrepreneurship education. $\mathrm{H}_{02}$ : There is no significant difference between main course of study and attitude of students towards entrepreneurship education.

$\mathrm{H}_{03}$ : There is no significant difference between age and attitude of students towards entrepreneurship education.

\section{Methodology}

The population of the study consisted of all final year students from Auchi polytechnic, Ambrose Alli University and Benson Idahosa University. The population of the final year students in these three tertiary institutions was about 30,000 during the 2019/2020 academic section. A total of 529 respondents were randomly selected using the simple random sampling technique. The sample size was further stratified into male and female using the stratified random sampling technique. In all a total of 284 males and 245 females constitute the sample size.

The instrument used consists of two sections, A and B. Section A sought demographic data on age, gender and faculty into which the student's main course is located, while section B contained 18 items that elicit information from students on their attitudes towards entrepreneurship education. A four-point Likert scale of Strongly Agree (SA), Agree (A), Disagree (D) and Strongly Disagree (SD) is used. A mean value score of 2.5 and above is accepted as 'agreed' while lower than 2.5 is 'disagree'. The decision value is gotten by $[(1+2+3+4) / 4]$.

The validity of the instrument was established through content validity. It was subjected to scrutiny by experts in measurement and evaluation. Based on their corrections and suggestions, the final version of the instrument was drawn. Reliability was tested using Cronbach Alpha; giving a value of 0.87 .

Copies of the instrument were administered personally and via email with the help of research assistants following the covid-19 restrictions which caught up with us during questionnaire administration. The emailed questionnaires were returned within 24hours. The analysis was done using percentages, mean and standard deviations on SPSS and Z-test on Microsoft Excel. The decision rule on the test of hypothesis is to reject the null hypothesis if the $\mathrm{Z}$-calculated is greater than the critical value of the Z-statistic at the $5 \%$ level of significance.

\section{Results}

\section{Table 1: Demographics}

\begin{tabular}{|l|c|c|}
\hline Characteristics & Frequency & Percentage(\%) \\
\hline Age & & 0 \\
$<15$ & 0 & 33.8 \\
$16-20$ & 179 & 56.4 \\
$21-24$ & 298 & 9.8 \\
25 and above & 52 & $\mathbf{1 0 0}$ \\
Total & $\mathbf{5 2 9}$ & \\
\hline Sex & & 53.7 \\
Male & 284 & 46.3 \\
Female & 245 & $\mathbf{1 0 0}$ \\
Total & $\mathbf{5 2 9}$ & 14.4 \\
\hline Course of study & & 25.3 \\
Sciences & 76 & 31.2 \\
Business/mgt & 134 & 16.3 \\
Social sciences & 165 & 12.9 \\
Engineering & 86 & $\mathbf{1 0 0}$ \\
ICT & 68 & $\mathbf{5 2 9}$ \\
Total & & \\
\hline
\end{tabular}

The summary features in Table 1 above show the age, gender and main course of study of the respondents. No respondent was found to be below 15 years while $179(33.8 \%)$ of the respondents fell within the age bracket of 16 to 20 years. $298(56.4 \%)$ respondents were aged between 21 and 24 years while $52(9.8 \%)$ were aged 25 years and above. O gender, 284 respondents accounting for $53.7 \%$ were males while the remaining 245 , representing $46.3 \%$ were females. Table 1 also reveal that 76 (14.4\%) of the respondents were from the Sciences; $134(25.3 \%)$ from Business/management; 165 (31.2\%) from Social sciences; 86 (16.3\%) from Engineering while the remaining $68(12.9 \%)$ were from ICT related courses. 
Table 2: Mean and standard deviation of items in the table

\begin{tabular}{|c|c|c|c|c|}
\hline S/no & Item & Mean & S.D & Remark \\
\hline 1 & I enjoyed entrepreneurship lectures & 3.16 & .592 & Agreed \\
\hline 2 & I enjoyed the practical sections with resource persons. & 2.71 & .552 & Agreed \\
\hline 3 & The lectures aroused my interest in being an entrepreneur & 3.22 & .576 & Agreed \\
\hline 4 & Entrepreneurship education is a distraction from my main course of study & 2.64 & .875 & Agreed \\
\hline 5 & Entrepreneurship education is as important as my main course of study & 2.75 & .683 & Agreed \\
\hline 6 & $\begin{array}{l}\text { entrepreneurship education has helped me to be more sensitive to business } \\
\text { needs/opportunities in my environment }\end{array}$ & 3.43 & .528 & Agreed \\
\hline 7 & $\begin{array}{l}\text { Entrepreneurship education gave me opportunity to meet successful business people } \\
\text { who have motivated me. }\end{array}$ & 3.04 & .528 & Agreed \\
\hline 8 & $\begin{array}{l}\text { Even if am able to get a regular employment, i will run a private business to employ } \\
\text { others. }\end{array}$ & 3.75 & .471 & Agreed \\
\hline 9 & Entrepreneurship education has enabled me to identify business opportunities. & 3.43 & .518 & Agreed \\
\hline 10 & Entrepreneurship education has enabled me know how to develop a business plan & 3.05 & .516 & Agreed \\
\hline 11 & Entrepreneurship education has enabled me to help run a business for somebody. & 3.74 & .450 & Agreed \\
\hline 12 & Entrepreneurship education has enabled me develop skills to create my own business. & 3.71 & .537 & Agreed \\
\hline 13 & $\begin{array}{l}\text { Entrepreneurship education has enabled me to handle risks and changes that can affect } \\
\text { my business. }\end{array}$ & 2.86 & .382 & Agreed \\
\hline 14 & Entrepreneurship education has enabled me to test my business ideas if they will work. & 3.12 & .558 & Agreed \\
\hline 15 & \multirow{2}{*}{$\begin{array}{l}\text { Overall, i am satisfied with the way entrepreneurship programme is being run in my } \\
\text { school. }\end{array}$} & 1.53 & .674 & Disagree \\
\hline 16 & & \multirow[t]{2}{*}{3.53} & \multirow[t]{2}{*}{.532} & \multirow[t]{2}{*}{ Agreed } \\
\hline & I want to be self-employed after school. & & & \\
\hline 17 & Opening a business is important to me. & 3.53 & .522 & Agreed \\
\hline 18 & $\begin{array}{l}\text { The entrepreneurship education programme has effectively prepared me for self- } \\
\text { employment }\end{array}$ & 2.85 & .622 & Agreed \\
\hline
\end{tabular}

Table 2 above presents 18 items used to solicit information as to level of agreement or disagreement to various statements from the respondents. The mean score ranged between 1.53 and 3.75. The variation around the mean was checked by the coefficient of variation and revealed that the standard deviations are small and therefore a good representation of individual consensus.

Item 1 and 2 revealed a mean score of $3.6(\mathrm{~S} . \mathrm{D}=0.59)$ and $2.71(\mathrm{~S} . \mathrm{D}=0.55)$ respectively which indicates a general agreement by the students that they enjoyed both the entrepreneurship lectures as well as the practical sections by established business people who act as resource persons. This shows a positive attitude. Item 3 with a mean score of $3.22(\mathrm{~S} . \mathrm{D}=0.58)$ showed that the lectures aroused the interest of the students in being entrepreneurs but item 4 with mean score of 2.64 revealed that entrepreneurship studies is a distraction from their main course of study even though the perceive its importance as revealed by the mean score of item 5 . Item 5 is taken as our measure of attitude of the respondents to entrepreneurship education.

Items 9 to 14 with mean scores of $3.43(\mathrm{~S} . \mathrm{D}=0.52) ; 3.05(\mathrm{~S} . \mathrm{D}=0.516) ; 3.74$ (S.D. $=0.450) ; 3.71$ (S.D. $=$ $0.537) ; 2.86(\mathrm{~S} . \mathrm{D}=0.382)$ and $3.12(\mathrm{~S} . \mathrm{D}=0.558)$ respectively indicates general agreement by the respondents that entrepreneurship education has enabled them identify business opportunities, develop a business plan, run a business for somebody, handle risks and changes that can affect their business as well as enabled them to be able to test their business ideas if they will work.

Item 15 revealed a disagreement as to satisfaction with the way entrepreneurship programme is being run in the various schools as the low mean score of $1.53(\mathrm{~S} . \mathrm{D}=0.674)$ indicate. Item 16 indicates a general agreement by the respondents to be self employed after school with a mean score of 3.53 (S.D = 0.532). On item 17 with mean score of $3.53(\mathrm{~S} . \mathrm{D}=0.522)$ it indicates agree to the statement of opening a business being important to the respondent, finally, item 18 with mean score of $2.85(S . D=0.627)$ revealed agree to the argument that the program has effectively prepared them for self-employment.

\section{Test of hypothesis}

$H_{01}$ : There is no significant difference between gender and attitude of students towards entrepreneurship education. 
Table 3: Summary of Z-test results on gender differences in students' attitude towards entrepreneurship education

\begin{tabular}{|c|c|c|}
\hline & Calculated value & Critical value \\
\hline Z-test & -35.0429 & 1.959964 \\
\hline
\end{tabular}

Table 3 shows Z-calculated is -35.0429 and since the absolute value of the $\mathrm{Z}$ calculated is greater than critical $\mathrm{Z}$ (of \pm 1.96 ) at $5 \%$ level of significance, the null hypothesis is rejected and it is therefore concluded that there is significant difference between gender and student's attitude towards entrepreneurship education.

$H_{02}$ : $\quad$ There is no significant difference between main course of study and attitude of students towards entrepreneurship education.

Table 4: Summary of Z-test results on area of study differences in students' attitude towards entrepreneurship education

\begin{tabular}{|c|c|c|}
\hline & Calculated value & Critical value \\
\hline Z-test & 2.0807453 & 1.959964 \\
\hline
\end{tabular}

Table 4 produced a Z-value of 2.0808. Since $Z$ calculated is greater than critical $Z$ (of \pm 1.96 ), the null hypothesis is rejected and therefore we conclude that there is significant difference between area of study and the attitude of students towards entrepreneurship education.

H03: There is no significant difference between age and attitude of students towards entrepreneurship education.

Table 5: Summary of Z-test results on age differences in students' attitude towards entrepreneurship education

\begin{tabular}{|c|c|c|}
\hline & Calculated value & Critical value \\
\hline$Z$-test & 0.18896895 & 1.959964 \\
\hline
\end{tabular}

Table 5 gave a Z-value of 0.18897 . Since $\mathrm{Z}$ calculated is less than critical $\mathrm{Z}$ (of +1.96 ), we fail to reject the null hypothesis and hence conclude that there is no significant difference between age and students' attitude towards entrepreneurship education.

\section{Discussion of results}

The findings of this study revealed that majority of the respondents have a positive attitude towards entrepreneurship education. This finding is consistent with previous findings on attitude/perception of students towards entrepreneurship both within and outside Nigeria. (Rudhumbu et al, 2016; Hussain et al, 2018; Adeeko et al, 2016; Buba et al, 2015 and Otu et al, 2017). This positive attitude was expected as such attitude towards entrepreneurship education will promote learning especially classroom or group learning as proposed by the social constructivism theory of learning. Overtime, there will be improvement in the resultant effect of entrepreneurship education in Nigerian tertiary institutions of learning.

The study also found a positive attitude among respondents in their desire to be entrepreneurs after school. This is consistent with the findings of Buba et al, (2015); Pulka et al, (2014) and Rudhumbu et al, (2016). The aim of entrepreneurship education is to create the entrepreneurial spirit among graduates such that they can provide employment for themselves and others. During the discussion sections with some respondents they had the desire to be entrepreneurs but have the fear of some issues like funding and finding collateral for startup funds where they have commercial banks willing to lend. Inspite of this fear, the final analysis revealed that the students have a positive attitude towards being entrepreneurs after school.

The study found that the attitude of students to entrepreneurship education can be affected by their gender as corroborated by Rudhumbu et al (2016) and Abdelraheem \& Rand, (2019). The place of gender imbalance is found in almost every facet of human functions. There upbringing of male children grooms them towards being financial sponsors while females are just trained to have children and man the home front (Isere \& Imonikhe, 2018). Attitude of students' towards entrepreneurship education being affected by gender may be as a result of this grooming given to children to fit them into certain roles defined by society s for male/female gender.

This study also revealed that main course of study does affect the attitude of students towards entrepreneurship education. This is in sync with the findings of Ango and Kyari (2018). This finding may be as a result of the fact that the students already have what they consider a large number of courses to do. They therefore view entrepreneurship education as an added burden. This can be adjusted by streamlining the content of entrepreneurship education in each faculty to fit students of that faculty.

Finally, the study revealed a need to adjust the overall program as is being run currently. Upon discussions with the respondents many expressed the need to adjust the program in the sense of devoting more time to practical sessions and helping the students with actual projects like running some arms of businesses owned by their various schools. 


\section{Conclusion}

The attitude of students towards entrepreneurship education is positive and will produce the needed employment generation desire of the government as it is streamlined to be more relevant so that students do not view it was a distraction from their main course of study but as an aid to enhancing their social and economic status in the future. There is need to make the course more attractive to students.

\section{Recommendation}

Based on the findings from this research, we make the following recommendation:

a. Students should be assisted to have free hands-on-training in industries of their choice during holidays so they can practicalize the theories learnt in class. This will go a long way to strengthen their perceived relevance of the course.

b. The lectures and practical sections should be made more attractive by giving specialized training to entrepreneurship educators and resource persons.

c. There is need to adjust/streamline the entrepreneurship education syllabus to be faculty-specific so the students can see its relevance in their main areas of study.

\section{Acknowledgements}

The authors sincerely acknowledge and appreciate the financial sponsorship of this research by the Tertiary Education Trust Fund (TETFUND), Nigeria

\section{References}

Abdelraheem M. A. \& Rand E. B. (2019). Students' attitude towards entrepreneurship at Princess Sumaya University for Technology. Journal of Entrepreneurship Education. 22(1) :11-19.

Adebayo, O. \& Kolawole, J.A. (2013). The historical Background of Entrepreneurial Development In Nigeria: its Gains, Shortcomings and Needful. Journal of Emerging Trends in Economics and Management Sciences (JETEMS). 4(5):493-500.

Adeeko. A.; Bifarin, J. O.; \& Umunna, M.O. (2016). Perception and attitude of students towards entrepreneurship education in Nigeria (Ondo State as a case study). Continental Journal of Social Sciences. 9 (1): $17-25$.

Ajike, F.R. ; Nnorom, G; Akinlabi, B.H.; Onyia, V.A. \& Kwarbai, J.D. (2015). Entrepreneurship education and entrepreneurial intentions: the role of theory of planned behavior. International Journal of Advanced Research in Social Engineering and Development Strategies. 3(1): 118 - 135.

Allawadi, S.C. (2010). Entrepreneurship challenges in the $21^{\text {st }}$ century. Mumbai: Indian Institute of Materials Management.

Alika, H.I. (2013). Towards Enhancing Girl child education in Nigeria: Implications for counseling. The Counsellor. 32(1\&2) $66-74$

Amanamah, R. B. (2017). Tertiary Students' Attitude towards Entrepreneurship Education in Ghana. Journal of Small Business and Entrepreneurship Development. 5(2) : 125-133.

Ango, Y. \& Kyari, J.J. (2018). Impact of undergraduate students attitude towards entrepreneurship education in Kaduna state University. Crawford Journal of Business and Social Sciences. 3(11): 92-102.

European Commission (2011). Entrepreneurship education: enabling teachers as a critical success factor: Entrepreneurship Unit Directorate - General Enterprise and Industry, Brussels.

FRN (2004). National Policy on Education. $4^{\text {th }}$ edition. Lagos: NERDC Press.

GSI Teaching and Resource Center (2020). Overview of learning theories. Retrieved online at gsi.berkeley.edu/gsi-contents/learning-theory-research/overview-of-learning-theories/ on 20 January, 2021.

Hussain, T.; Hashmi, A. \& Gilani, M. (2018) Attitude towards Entrepreneurship: An Exploration of Technology Education Students . Bulletin of Education and Research. 40(1) : 131-139.

Isere, V.O.M. \& Imonikhe, J.S. (2018). Social and economic implications of girl child education in Nigeria: a case study of Auchi Comminuty and environs. International Journal of Humanities and Social Sciences. 6(4): $202-219$.

Lawal, K.K. (2016). Importance of the Nigerian girl-child education. Retrieved online at premiumtimesng.com/importance-of-the-nigerian-girlchild-education on $24^{\text {th }}$ Feb. 2018.

Lawan, U.M.; Envuladu, E.A.; Mohammad, M. A.; Wali, N. Y. \& Mahmoud, H.M. (2015). Perceptions and attitude towards entrepreneurship education programme, and employment ambitions of final year undergraduate students in Kano, Northern Nigeria. International Journal of Education and Research. 3(11): $229-242$.

Ojiefo, S.A. (2012). A handbook on entrepreneurial development in Nigeria. Ekpoma: Emmasco Printers.

Okoli, N \& Allahma, E.J. (2014). Entrepreneurship education from pre-colonial to post-independence Nigeria. Merit Research Journal. 3(10): 252 - 256.

Otu, B. D.; Eduwem, J. D. \& Umoinyang, I. E. (2017). Attitude of students toward entrepreneurship studies in the 
University of Calabar, Cross River State. Journal of Research \& Method in Education. 7(2): 14-17.

Pulka, B.M.; Ayuba A. \& Rimamnde, R (2015). The effects of entrepreneurship education on university students' attitude and entrepreneurial intention. European Journal of Business and Management. 7(20): 149-157.

Pulka, B.M.; Rikwentishe, R. \& Ibrahim, B. (2014). An evaluation of students' attitude towards entrepreneurship education in some selected universities in North East Nigeria. Global Journal of Management and Business Research. 14(8): 1-8.

Rudhumbu, N.; Svotwa, D.; Munyanyiwa, T. \& Mutsau, M. (2016 ) Attitudes of Students towards Entrepreneurship Education at Two Selected Higher Education Institutions in Botswana: A Critical Analysis and Reflection . Academic Journal of Interdisciplinary Studies. 5(2) ; 84 - 94.

Utomi, J.M. (2020). National Policy on education and meeting 202 demands. Retrieved online at dailytrust.com/national_policy_on_education_and_meeting_2020_demands on 12 ${ }^{\text {th }}$ December, 2020.

Wikipedia (2020). Education. Retrieved at en.wikipedia.org/wiki/education on $17^{\text {th }}$ January, 2021.

Wikipedia (2020). Learning theories. Retrieved at en.wikipedia.org/wiki/learning-theories on 17 th January, 2021.

Wikipedia (2020). Entrepreneurship. Retrieved at en.wikipedia.org/wiki/learning-theories on 13 ${ }^{\text {th }}$ January, 2021. 